\title{
Choice of equal effects with unequal efforts: A way to quantify the law of least effort
}

\author{
J. D. KEEHN \\ Atkinson College, York University, Downsview, Ontario M3J 2R7, Canada
}

\begin{abstract}
Four white rats were trained to press two differentially weighted bars scheduled to provide reinforcement at 30 -sec variable intervals concurrently. As response force on one bar was increased, response rate on that bar decreased and response rate on the other increased, and vice versa. Reinforcement rates on each bar remained nearly equal over force requirements up to $45 \mathrm{~g}$, but at $60 \mathrm{~g}$, reinforcement rate on a bar declined. No simple effort-matching relationship comparable to Herrnstein's matching law was found.
\end{abstract}

Herrnstein (1961) discovered that in a choice situation in which response forms are equivalent, the relative rate of each response equals its relative rate of reinforcement. This case, which expresses an elegantly simple relationship when equal responses have unequal effects, has been confirmed and extended by numerous investigations (Bradshaw \& Szabadi, in press; de Villiers, 1977). However, the opposite case, in which unequal responses have equal effects, also merits attention.

The unofficial law of least effort suggests that this case is unobtainable, because the least effortful of alternative responses to an incentive should displace the others entirely. This is the state of affairs with concurrent ratio reinforcement schedules (with ratio size representing effort; Keehn, 1964), in which the response reinforced with the smaller ratio is normally emitted exclusively (Herrnstein \& Loveland, 1975). But when rats have alternative routes from startboxes to goalboxes in a maze, they switch among paths through the maze and do not always take the shortest (Olton, 1979). The present study attempts to quantify this phenomenon in a barpressing situation in which responses on differentially weighted bars are programmed to receive identical schedules of reinforcement. Chung (1965) describes a similar experiment with pigeons.

\section{METHOD}

\section{Subjects}

Four naive male Wistar rats were maintained in individual cages at $80 \%$ of their free-feeding body weights (based on weights at 100 days of age) over the course of the experiment, which lasted 13 weeks for Subjects M5 and M6 and 6 weeks for Subjects M7 and M8. The animals were fed at the end of experimental sessions and had access to water at all times.

This work was supported by a grant from the Research Committee of Atkinson College, York University. I am grateful to Arnie Mayers for help in collecting the data. Reprints may be obtained from J. D. Keehn, Atkinson College, York University, Downsview, Ontario M3J 2R7, Canada.
Table 1

Experimental Timetable Showing the Dead Weight Attached to Each Bar in Successive Weeks

\begin{tabular}{rcc} 
& \multicolumn{2}{c}{ Weight (in Grams) } \\
\cline { 2 - 3 } Week & Bar 1 & Bar 2 \\
\hline \multicolumn{3}{c}{ Subjects M5 and M6 } \\
$3-7$ & 30 & 15 \\
$8-11$ & 45 & 15 \\
$12-13$ & 60 & 15 \\
& 30 & 10 \\
$1-3$ & Subjects M7 and M8 & 15 \\
$4-6$ & 30 & 10 \\
\hline
\end{tabular}

\section{Apparatus}

A standard $29 \times 23.5 \times 19 \mathrm{~cm}$ Grason-Stadler two-bar chamber (Type E3125B) was enclosed in a ventilated soundattenuating chest. Both bars were employed and were counterweighted such that a force of at least $10,15,30,45$, or $60 \mathrm{~g}$ $(.098, .147, .294, .441$, or $.588 \mathrm{~N})$ defined a response. A defined barpress activated relay scheduling and recording equipment in an adjoining room. Barpresses below defined force levels were not recorded.

\section{Procedure}

All subjects were trained in a single session to press each of the bars, with continuous reinforcement available for each bar concurrently. In all cases, the minimum forces required to activate Bar 1 and Bar 2, respectively, were $30 \mathrm{~g}(.294 \mathrm{~N})$ and $15 \mathrm{~g}(.147 \mathrm{~N})$, and the session was terminated when 50 reinforcers were secured, some from each bar. Thereafter, reinforcers were scheduled at variable (VI) 30-sec intervals for each bar independently. Sessions lasted until 50 reinforcers were secured, and they were run for 5 days/week. The minimum force needed to depress a bar in all sessions in a week is shown in Table 1 .

\section{RESULTS}

Figure 1 shows the median number of responses on each bar per session in the final week of each experimental condition. All subjects pressed Bar 2, the lighter bar, more often than Bar 1 on all occasions, and in most cases, contrast effects can be seen. Thus, for M5 
and $\mathrm{M} 6$, in Weeks 2, 7, and 11, the force required to press Bar 1 increased from $.294 \mathrm{~N}$ to $.441 \mathrm{~N}$ to $.588 \mathrm{~N}$, and Bar 1 responses declined accordingly. At the same time, the corresponding numbers of responses on Bar 2 increased, although the force required to depress this bar was constant at $.147 \mathrm{~N}$. In Week 13, numbers of responses on Bar 1 increased as the force needed to depress it decreased from $.588 \mathrm{~N}$ to $.294 \mathrm{~N}$, but the smaller decrease, from $.147 \mathrm{~N}$ to $.098 \mathrm{~N}$, in the force required to depress Bar 2 led to a decrease rather than an increase in Bar 2 presses.

In the cases of M7 and M8, the force required to depress Bar 1 was unaltered $(.294 \mathrm{~N})$ between Weeks 3 and 6 , but the number of responses on this bar decreased as the force required to depress Bar 2 was dropped from $.147 \mathrm{~N}$ to $.098 \mathrm{~N}$. At the same time, the number of Bar 2 responses increased. These results differ from those of Chung (1965), who found in a similar experiment with pigeons that the response rate on one key was not affected by the force required to peck the other key.

Table 2 summarizes response and reinforcement rates for each bar separately in the final week of each experimental condition. The right-hand column shows the matching ratio, which in Herrnstein's (1961) equation for equivalent responses is unity. This value is approached when the Bar 1 vs. Bar 2 force requirements were in the ratio of $2: 1$, but with higher effort ratios, the matching ratio declines such that with effort ratios of $3: 1$ and $4: 1$, the matching ratios approximate .7 and .4 , respectively.

With respect to response and reinforcement rates, both fell for Bar 1 as the force required to depress this bar increased, but response rate changes consider-

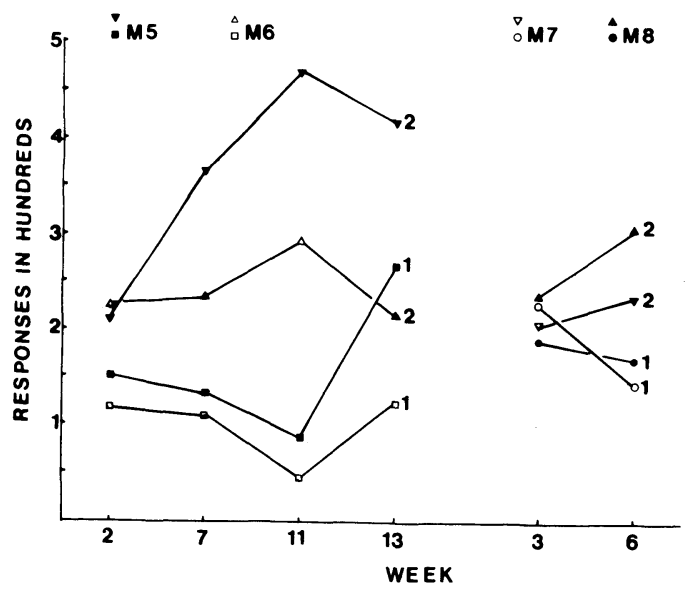

Figure 1. Median numbers of barpresses per session on Bar 1 and Bar 2 in the final week of each experimental condition. For Subjects M5 and M6, Bar 1 counterweights in Weeks 2, 7, and 11 were $30 \mathrm{~g}, 45 \mathrm{~g}, 60 \mathrm{~g}$, and Bar 2 counterweight was $15 \mathrm{~g}$. In Week 13, Bar 1 and Bar 2 counterweights were $30 \mathrm{~g}$ and $10 \mathrm{~g}$, respectively. For Subjects M7 and M8, Bar 1 counterweight was $30 \mathrm{~g}$ in Weeks 3 and 6 , and counterweights on Bar 2 were $15 \mathrm{~g}$ and $10 \mathrm{~g}$ in these weeks, respectively.
Table 2

Mean Rate of Response and Rate of Reinforcement During the Final Week With the Designated Dead Weights Attached to Each Bar, and Corresponding Matching Ratios

\begin{tabular}{|c|c|c|c|c|c|c|}
\hline \multicolumn{2}{|c|}{$\begin{array}{c}\text { Weight } \\
\text { (in Grams) }\end{array}$} & \multicolumn{2}{|c|}{$\begin{array}{l}\text { Responses } \\
\text { per Minute }\end{array}$} & \multicolumn{2}{|c|}{$\begin{array}{c}\text { Reinforcements } \\
\text { per Minute }\end{array}$} & \multirow{2}{*}{$\begin{array}{c}\text { Matching } \\
\text { Ratio }\end{array}$} \\
\hline Bar 1 & Bar 2 & R1 & R2 & $\mathrm{S} 1$ & S2 & \\
\hline \multicolumn{7}{|c|}{ Subject M5 } \\
\hline $\begin{array}{l}30 \\
45 \\
60 \\
30\end{array}$ & $\begin{array}{l}15 \\
15 \\
15 \\
10\end{array}$ & $\begin{array}{r}10.2 \\
8.3 \\
6.4 \\
18.3\end{array}$ & $\begin{array}{l}12.9 \\
24.0 \\
30.4 \\
30.0\end{array}$ & $\begin{array}{l}1.6 \\
1.6 \\
1.4 \\
1.8\end{array}$ & $\begin{array}{l}1.7 \\
1.8 \\
1.8 \\
1.8\end{array}$ & $\begin{array}{l}.91 \\
.55 \\
.39 \\
.76\end{array}$ \\
\hline \multicolumn{7}{|c|}{ Subject M6 } \\
\hline $\begin{array}{l}30 \\
45 \\
60 \\
30\end{array}$ & $\begin{array}{l}15 \\
15 \\
15 \\
10\end{array}$ & $\begin{array}{l}7.4 \\
5.6 \\
2.5 \\
7.6\end{array}$ & $\begin{array}{l}15.2 \\
13.5 \\
16.0 \\
14.3\end{array}$ & $\begin{array}{r}1.5 \\
1.3 \\
.9 \\
1.6\end{array}$ & $\begin{array}{l}1.8 \\
1.8 \\
1.8 \\
1.8\end{array}$ & $\begin{array}{l}.71 \\
.69 \\
.41 \\
.74\end{array}$ \\
\hline \multicolumn{7}{|c|}{ Subject M7 } \\
\hline $\begin{array}{l}30 \\
30\end{array}$ & $\begin{array}{l}15 \\
10\end{array}$ & $\begin{array}{r}15.1 \\
9.4\end{array}$ & $\begin{array}{l}13.1 \\
14.7\end{array}$ & $\begin{array}{l}1.6 \\
1.6\end{array}$ & $\begin{array}{l}1.7 \\
1.7\end{array}$ & $\begin{array}{c}1.10^{*} \\
.80\end{array}$ \\
\hline \multicolumn{7}{|c|}{ Subject M8 } \\
\hline $\begin{array}{l}30 \\
30\end{array}$ & $\begin{array}{l}15 \\
10\end{array}$ & $\begin{array}{l}12.8 \\
11.4\end{array}$ & $\begin{array}{l}14.3 \\
19.4\end{array}$ & $\begin{array}{l}1.5 \\
1.7\end{array}$ & $\begin{array}{l}1.5 \\
1.8\end{array}$ & $\begin{array}{l}.94^{*} \\
.76\end{array}$ \\
\hline
\end{tabular}

*Based on three values (all other means are based on five values).

ably exceeded reinforcement rate changes. In fact, except in one case with M6, reinforcement rates for each bar were relatively insensitive to force requirement differences, indicating that the experimental objective of equal results from unequal efforts was reasonably well achieved.

Figure 2 relates relative rate of response to relative effort of response. The abscissa represents the effort ratio (Bar 1 vs. Bar 2 force requirement) and the ordinate the ratio of obtained Bar 2 vs. Bar 1 response rates. If effort matching occurred such that the relative rate of Bar 2 presses equaled the relative effort of Bar 1 presses, the data points would lie on the oblique line in the figure. Mostly, they do not: When Bar 1 was two or three times heavier than Bar 2, Bar 2 was pressed at a lower relative rate than effort matching requires, and when Bar 1 was four times as heavy as Bar 2, the relative rate of Bar 2 presses exceeded the rate required for matching.

\section{DISCUSSION}

The law of least effort is plainly a law of lesser effort. On no occasion did the least effortful response occur exclusively, although this obviously would occur with higher values of the more effortful response. With the present values, in every comparison except one in Table 2, the rate of the lesser effortful response exceeded that of the more effortful response, and the greater the effort difference, the greater was the rate inequality. At the same time, in most cases, the rates of reinforcement of the alternative responses were approximately equal. The subjects responded less on the heavier bar, as expected, but they did not "equalize the amount of behavior per reinforcement across choices" (Herrnstein, 1979); they equalized the amount of 


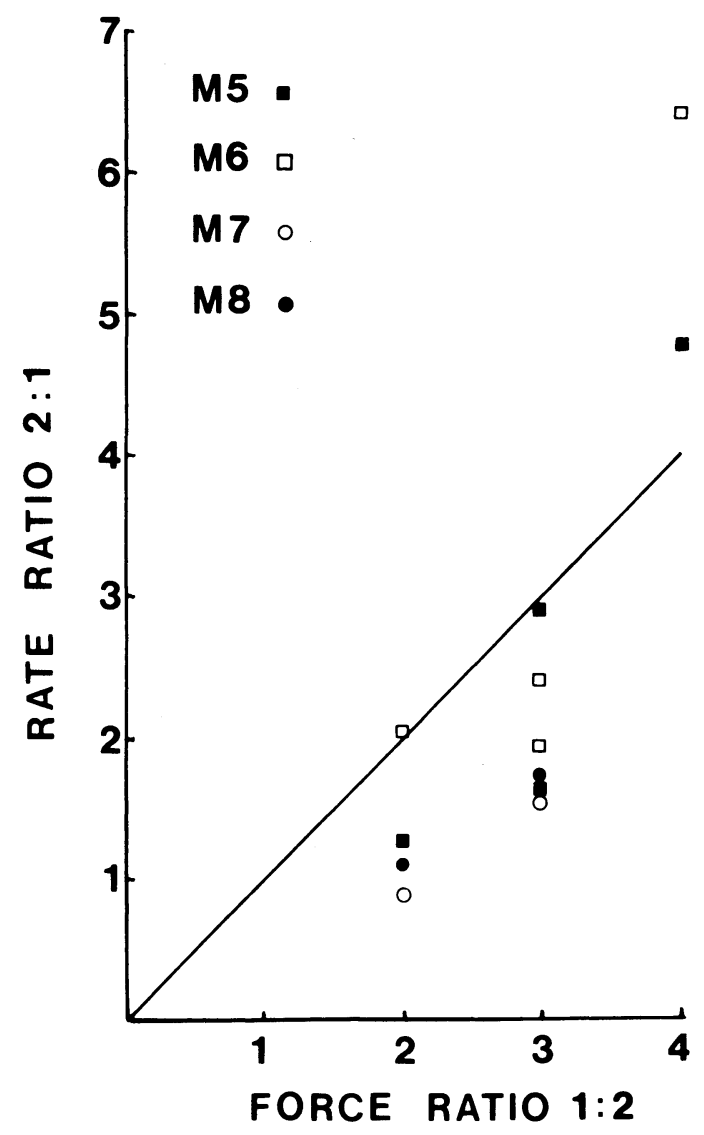

Figure 2. Ratio of Bar 2 to Bar 1 response rates as a function of the ratio of Bar 1 to Bar 2 force requirements. reinforcement per choice. At the heaviest weight, however $(60 \mathrm{~g}$ on Bar 1), response rate fell sufficiently to depress reinforcement rate, and, eventually, response and reinforcement rates would each fall to zero, obeying Herrnstein's law (Herrnstein \& Loveland, 1975) and the law of least effort together. But at other values, no simple relationship between effort on one bar and either response or reinforcement rate on the other bar emerged.

\section{REFERENCES}

Bradshaw, C. M., \& Szabadi, E. (Eds.). Recent developments in the quantification of steady-state operant behavior. New York: Elsevier, in press.

Chung, S. H. Effects of effort on response rate. Journal of the Experimental Analysis of Behavior, 1965, 8, 1-7.

DE Villie rs, P. A. Choice in concurrent schedules and a quantitative formulation of the law of effect. In W. K. Honig \& J. E. R. Staddon (Eds.), Handbook of operant behavior. Englewood Cliffs, N.J: Prentice-Hall, 1977.

HERRNSTE in, R. J. Relative and absolute strength of response as a function of frequency of reinforcement. Journal of the Experimental Analysis of Behavior, 1961, 4, 267-272.

Herrnste in, R. J. Derivatives of matching. Psychological Review, 1979, 86, 486-495.

Herrnste in, R. J., \& Loveland, D. H. Maximizing and matching on concurrent ratio schedules. Journal of the Experimental Analysis of Behavior, 1975, 24, 107-116.

Keenn, J. D. Cumulative confusion. Psychological Reports, $1964,14,942$.

Olton, D. S. Mazes, Maps and memory. American Psychologist, 1979, 34, 583-596.

(Received for publication February 17, 1981.) 